\section{领随 影故}

\section{第 23 回日本脳神経外科コングレス 『あたらしい社会の脳神経外科診療』}

大阪大学医学部脳神経外科

\section{吉峰 俊樹}

コングレスの会長に指名していただいたのは教授に就 任して間もなくの頃, 教室のあり方や脳神経外科の目指 す方向を考えている頃であった。この頃は医療を取り巻 く周辺環境にも動きがあり, 何かにつけ先行きが不透明 であった，専門性の高い脳神経外科領域にあっても学問 や技術だけでなく広く社会にも眼を向けなければ正しい 発展は難しいと危惧された。このような思いの中で, 次 のように『あたらしい社会の脳神経外科診療』をテーマ として第 23 回総会を開催した。

\section{ご挨拶：第 23 回日本脳神経外科コングレス総会}

\section{開催に向けて (拔粋)}

『あたらしい社会の脳神経外科診療』

第 23 回日本脳神経外科コングレス総会は 2003 年 5 月 16 日 (金) 〜 18 日（日）にかけて大阪で開催さ れます。

前回の総会は永田 泉会長の下，「的確な診断と治 療」を主題として素晴らしい内容でとり行われました。 「的確な診断と治療」は診療の最も重要な基本であり, 今回もこの精神を引き継いで生涯教育に役立つプログ ラムを企画致しました。

最近の医療界にあって日々感じることは，その全体 が大きく変貌しつつあることです。その一つは診療の 場に Evidence Based Medicine の概念が取り入れられ， 従来からの「的確な診断と治療」にも改めて「科学的 な裹付け」が求められるようになってきました。根拠 の定かでない診療は再検討し, 妥当性が科学的に証明 された診療を追求することが望まれます。

さらに大きな変化は，医学自体よりもむしろ周辺環 境の中で進夕つつあります。診療報酬にかかわる「施 設基準」や「医療費の包括化」「「自己負担率」の増加, 「新臨床研修制度」の導入,「医業広告の規制緩和」な ぞ，医療制度が変化し，また「手術件数」や「専門医 資格」、「医療事故」などに関する情報公開の動き，あ るいは「セカンドオピニオン」の推進など, 社会全体 が医療のあらゆる面に積極的に目を向けるようになっ てきました.

私どもはこのような変化に対応しつつ，あたらしい 社会の中でよりよい䛦療を目指す必要があります。第
23 回コングレス総会はこのような『あたらしい社会の 脳神経外科診療』を基本理念に掲げて準備して参りま した。

「Evidence and Questions」では，いくつかの疾患に ついてこれまでの診療データを振り返り，診療方針の 妥当性を支持する根拠の有無を再検討し，患者・家族 はもとより，他科の医師など第三者にも妥当性を証明 できる診療につなげたいと考えます。

「Current Neurosurgery」と「モーニングセミナー」 では, 進歩し, 拡大し続ける脳神経外科の最新の診療 技術を解説していただきます。

「ランチョンセミナー」では脳神経外科領域の「 New Fields・New Techniques」について紹介していただき, 「特別セッション」ではこれからの「医療制度のゆくえ」 について改めて理解を深めたいと思います。

その他，互いの診療技術について忌悼のない意見を 述べあう「イブニング・ビデオディスカッション」, 若 手の脳神経外科医の交流と懇親のための「若手脳神経 外科医フォーラム」などを企画致しました。

プログラムの構成と総会の運営には多くの先生方の ご指導とご支援が欠かせません，先生方におかれまし ては何卒宜しくご援助賜りますようお願い申し上げま す.

会場は大阪市の西端，大阪湾に面し，私どもが「大 阪南港」と呼びならわしている地域にあります。多く の商業施設が建設され活気づくこの大阪のベイエリア で，多くの先生方と再会できますことを楽しみにして おります。

第 23 回日本脳神経外科コングレス 会長 吉峰俊樹

\section{国内の学会の調査}

コングレス総会の特徴はすべてのプログラムを会長が 最終責任をもって構成することである，そのためには会 長自身が脳神経外科のすべての領域について知る必要が あると考え，2 年間の準備期間は国内のほとんどの関連 学会に参加した. が, 実際のプログラム編成ではこのよ うなにわか觔強では足らず，結局は多くの先生方にご意 見をいただくこととなった。 


\section{プログラムの内容}

プログラムは前記の趣旨に基づき, 脳神経外科関連の すべての領域をカバーすることとした，今後伸ばすべき 領域として血管内治療や沗髄外科の基礎を大きく取り上 げ，小児神経外科の EBM やスポーツ外傷の現状に注目 した。

講演の内容は日々の診療にすぐに役立つものとした. そのため基礎研究や未来的医療の話は取り扱わなかつ た。

\section{海外からの招聘}

海外から招聘する人物の選考にあたっては，会員の生 涯教育に益することを条件とした，脳動脈溜の血管内治 療国際共同研究 (ISAT) や新しい神経機能外科領域の 方々である。私的交流のある友人はあまり呼ばないこと になり申し訳なく思っている。しかし，会員のためのコ ングレスであるので, 会長個人の交友関係に左右される べきではないと今でも考えている。

\section{若手脳神経外科医フォーラム}

日本の勤務医のほとんどは医局（教室）の枠（壁）の 中で生涯を終える。異なった大学間の人事交流はそしい. このような医局システムの是非はともかくとして，日本 の将来を担う若手医師に対し，互いに他の教室の現状を 知る機会を設けるため, 若手脳神経外科医のための フォーラムを企画した。テーマは下記 3 題とし，それぞ れ7つの大学から発表者を推薦していただいた。若手医 師以外の参加も自由であるが，会長招宴の「裏番組」に あたり，私をはじめ全国の大学教授は参加できないよう になっていた。

「若手脳神経外科医フォーラム」のテーマ

（1）私の専門医試験受験対策・受験体験

(2) 私の卒後研修体験

(3) 私の海外留学体験

〜引き続き若手想親会 (参加無料) 〜

最も熱がこもったのは（1）のテーマであったとのこ とである。この専門医試験にまつわる状況は大学間で大 きく異なったという。すなわち，(1)毎年多くの受験生を 抱穴, 10 年以上にわたって完壁な過去問集が揃っている 大学, (2)受験生が少なく過去の情報がほとんど伝えられ ていない大学, (3)受験者が 1 年前から毎週集まり一緒に 勉強している大学, (4)受験準備として数力月間病棟勤務 を免除される大学，(5)受験準備に何の配慮もない大学，

(6)「全国的ネットワーク」により傾向と対策が瞬時に伝 わるグループ, (7)同一教公内の受験生は運命共同体と考 えている大学, (8)同一教室内でも受験生はライバル同士 と考えている大学, (9)試験に落ちても特別視されない大
学，10試験に落ちると将来に影響する（?）大学，など などと伝え聞いている.

\section{その後の反省：基礎研究をどこまで重視するか？}

教授就任当初は大学病院も関連施設もまずは優れた診

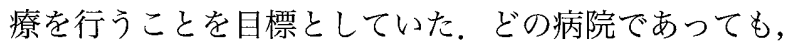
「脳神経外科は安心して診てもらえる」,「安心して手術し てもらえる」というのか脳神経外科発展の基礎と考元た からである. そのため, 研究, 特に基礎的研究は二の次 になっても致し方ないと考元た。前述のとおりコングレ スのプログラムでも日々の臨床に直結するものを選ん だ.

この考えはコングレス後もしばらく変わらなかった が，その後，基礎研究も軽んじてはならないのではと感 じはじめた，この思いは，藤枝平成記念病院脊髄脊椎疾 患治療センターの花北順哉先生に大阪で春䯣外科の講演 を打願いした際に決定的となった，花北先生の長い臨床 の歷史と素晴らしい手術や梁い学識に感動していたとこ ろ, 先生は最後に, 「基礎研究なくしては外科の未来はな い」と話された。臨床一筋の春䯣外科の大家としてこの 言葉は説得力があった，診療技術に臨床的改良を加える ことはもちろん重要であるが，そ机だけでは外科は発展 しない,「未来はない」と断定された。ドイッの Fahlbusch 先生も同じようなことをいわれた、基礎研究のない外科 医は内科医のしもべになるしかない」。

コングレスのような臨床医の生涯教育を担う総会で あっても基礎研究の話題についてそれなりに配慮すべき であったかと反省している。

\section{将来に望むもの}

コングレスを脳神経外科医の生涯教育の場と規定した 先輩方の慧腿には敬服している，医師は臨床経験を積む ことが最も有効な研鑽方法であり，いくら優れた講演を 聴いて感動してもそのまま身に付くかどうかは怪しい. にもかかわらず定期的にこの種の講演を聴くことは重要 である。講演などにより得た知識は実際に臨床の場で応 用されると実用的診療技術として身に付くのではないか と思う。

コングレス総会は会長が全責任をもってプログラムを 編成することになっている，その折々のテーマも会長の 個性が反映され，そのつど会員に新たな視点を提供して いるものと思わ机る。他に類をみない貴重な特徴である.

会長の個性のほか, 標準的知識や技術を毎年繰り返し て解説することも重要である．現在のコングレスはこの 双方をカバーしつつ歩んでいるように思える，この工 ニークな特性が今後とも継続され，多くの会員が参加さ れることを祈念している. 